International Journal of Life Sciences
Available online at http://sciencescholar.us/journal/index.php/ijls
Vol. 1 No. 2, August 2017, pages: 1 9
e-ISSN: 2550-6986, p-ISSN: 2550-6994
http://dx.doi.org/10.21744/ijls.vii2.27

\title{
Microbiological and Nutritional Qualities of Fermented Melon Seed Shells
}

\author{
Gideon I Ogu a ; Paul I Orjiakor b \\ Article history: Received 1 January 2017 ; Accepted in revised form 15 July 2017 ; Approved 25 July 2017 ; \\ Available online 1 August 2017
}

\section{Correspondence Author ${ }^{\text {a }}$}

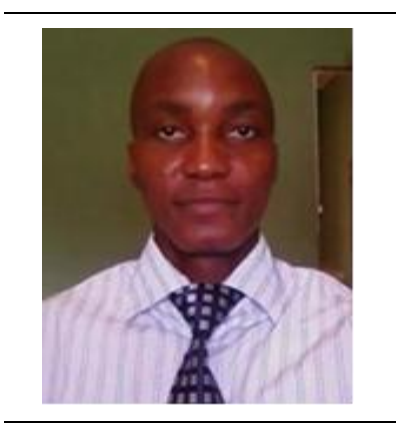

Keywords

Anti-Nutrient Content; Fermentation;

Food Supplement;

Livestock Feeds;

Melon Seed Shells;
Abstract

In Nigerian communities, melons seed shells are generated as waste after utilization of the pulp for economic and domestic purposes. In an attempt to derive wealth from these wastes, we decided to investigate the microbial and nutritional qualities of spontaneously fermented melon seed shells. The pulverized melon seed shells were spontaneously fermented in shake flask for a period of five (5) days at ambient temperature $\left(30 \pm 2{ }^{\circ} \mathrm{C}\right)$. The final product was then analyzed for microbial, proximate, mineral, and anti-nutrient qualities. The microbial load decreased from $10.1 \times 10^{6}-2.1 \times 10^{5} \mathrm{cfu} / \mathrm{g}$ after fermentation. The final $\mathrm{pH}$ of the fermented medium was 4.2. The microbial species belonging to genera of Bacillus, Micrococcus, Aerobacter, Rhizopus, Mucor, Aspergillus Penicillium and Candida were isolated from the unfermented sample, while Bacillus, Rhizopus, Aspergillus, Penicillium and Candida dominated the fermented sample. Fermentation caused a significant $(\mathrm{P}<0.05)$ increase in its crude protein contents, ash contents, moisture contents, some mineral contents, but a decrease in the crude fat, carbohydrate contents and other anti-nutrients (hydrogen cyanide, tannins and phytate) when compared with the unfermented controls. The findings from this study suggest that naturally fermented melon seed shell possess better and improved nutrient status over the unfermented, and thus may find potential application as nutrient fortifiers or feed supplements

a Department of Biological Sciences, Novena University, Ogume, Delta State, Nigeria

b Department of Microbiology, Ekiti State University, Ado Ekiti, Ekiti State, Nigeria 
e-ISSN : 2550-6986, p-ISSN : 2550-6994@ Copyright 2017. The Author. SS Journals Published by Universidad Técnica de Manabí. This is an open-access article under the CC BY-SA 4.0 license

(https://creativecommons.org/licenses/by-sa/4.0/) All rights reserved.

\section{Contents}

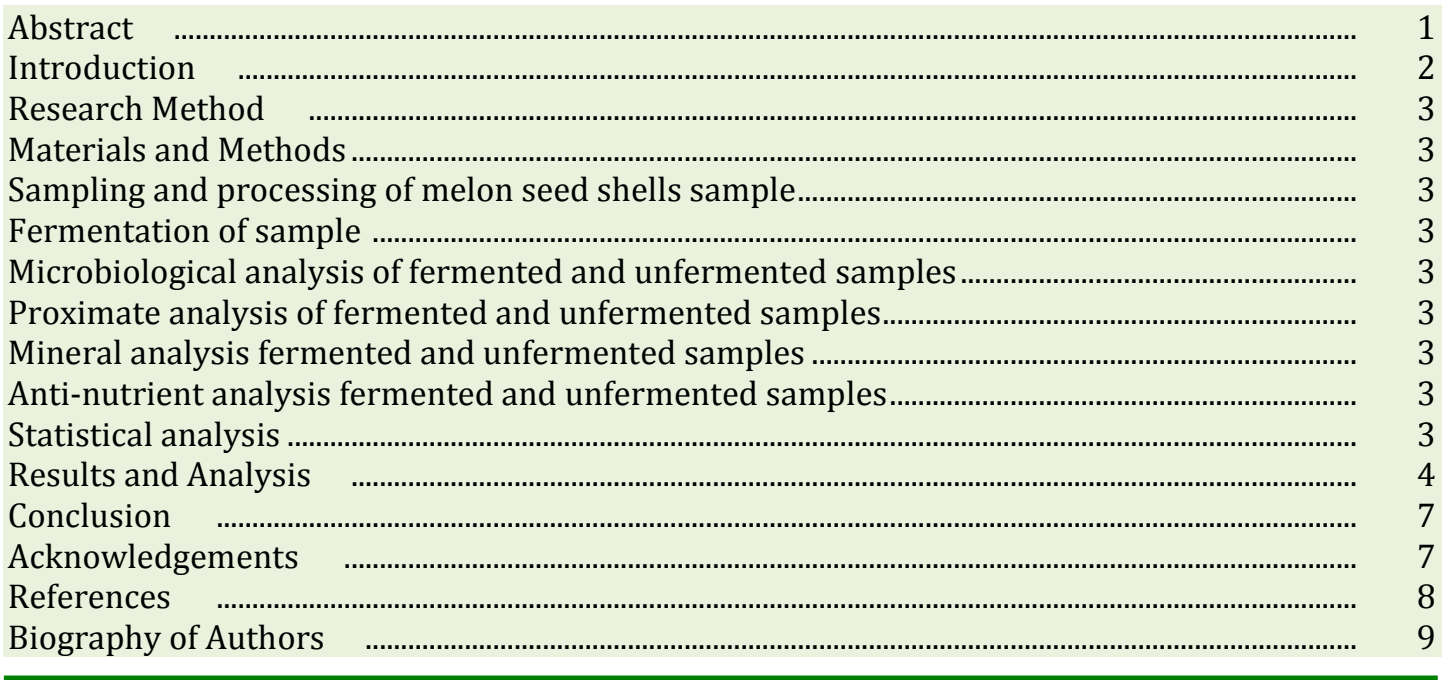

\section{Introduction}

The current upsurge in human population has impacted so much on the global status and balance of the environment. Human activities keep on generating large amounts of waste such as crop residues, solid waste from mines, municipal agricultural and industrial activities. They may become a nuisance and sources of pollution if not well managed. It is therefore important to handle them judiciously to avoid health problems, since these wastes may habour pathogenic microorganisms (Ledward et al., 2003). Agricultural wastes, including wood, herbaceous plants, crops and forest residues, as well as animal wastes are potentially huge source of energy. In Nigeria, large quantities of these wastes are generated annually and are vastly underutilized. The practice is usually to burn them or leave them to decompose. Studies have shown that these residues could be processed through fermentation for useful products of diverse applications.

In Nigeria, melon (Colocynthis citrullus vulgaris) is a widely cultivated annual crop mainly for its seeds from which a number of products could be obtained. The seeds are edible and consumed in virtually all parts of Nigeria and in many other parts of the world (Ogbonna, 2013). In Nigeria, the seeds are processed daily by private and commercial individuals into food condiments and other special delicacies (Adam et al., 2011). The processing of melon to get the seeds involves manual or mechanical separation or shelling of the seed to obtain the required edible pulp. This has led to the generation of large quantity of melon seed shell wastes which are later dumped indiscriminately along road sides and any available spaces without recourse to their health risks and environmental implications.

In an attempt to derive wealth from these wastes, this study was therefore undertaken to assess the microbiological and proximate status of naturally fermented melon seed shells. Fermentation has been known as the oldest microbiological means of producing wholesome, durable, and nutritionally rich food products 


\section{Research Method}

\section{Materials and Methods}

\section{Sampling and processing of melon seed shells sample}

Melon seed shells were collected from dumpsites along Obiaruku-Amai road and transported in a clean black polyethelene bag to the laboratory for processing within $1 \mathrm{hr}$. At the laboratory, the melon shells washed with sterile distilled water to remove unwanted materials were spread on the work bench to air dry for a week. They dried sample were milled using electric blender to fine particles before there were used for analysis

\section{Fermentation of sample}

Three hundred grams $(300 \mathrm{gm})$ of the pulverized sample was weighed into sterile plastic bucket containing sterile distilled water in the ratio of $1: 2(\mathrm{w} / \mathrm{v})$. The content was thoroughly mixed, covered with a clean cheese cloth and allowed to ferment spontaneously for 5 days under ambient temperature $\left(30 \pm 2^{\circ} \mathrm{C}\right)$. The experimental set up was done in triplicate. After five days, the fermented samples were then analysed for microbial quality, proximate, mineral and antinutritionally contents using standard biochemical techniques

\section{Microbiological analysis of fermented and unfermented samples}

One millilitre $(1 \mathrm{ml})$ aliquot sample each of the fermented and unfermented products was serially diluted 10 -fold and cultured on Nutrient Agar (Hi-media) and Potato Dextrose agar (Himedia) (supplemented with antibiotics) (Ogu et al., 2013). The plates were incubated at ambient temperature $\left(28 \pm 2^{\circ} \mathrm{C}\right)$ for $24-72 \mathrm{hrs}$. The bacterial and fungal colonies that developed were enumerated and reported as total heterotrophic and fungal counts ( $\mathrm{cfu} / \mathrm{ml})$. The colonies were further purified and identified using their cultural morphology cellular morphology and biochemical characteristics as described earlier (Barnett and Hunter, 1972; Alexopoulos and Mims, 1979; Holt et al., 2002)

\section{Proximate analysis of fermented and unfermented samples}

Proximate analysis of the dried samples for moisture, crude protein, crude fat, ash, fiber and carbohydrate contents were carried out in triplicates according to standard methods of AOAC (1990).

\section{Mineral analysis fermented and unfermented samples}

Five grams ( $5 \mathrm{~g}$ ) of each sample was dried to ash using an electric furnace at $600^{\circ} \mathrm{C}$ for 4 $6 \mathrm{hrs}$ hrs. The resulting ash was cooled in a desiccator and weighed. The ash was then dissolved with $2 \mathrm{ml}$ of concentrated $\mathrm{HCl}$ and few drops of concentrated $\mathrm{HNO}_{3}$ were added. The solution was placed in boiling water bath and evaporated almost to dryness. The content was then transferred to $100 \mathrm{ml}$ volumetric flask and diluted to volume with deionized water. This solution was used in the determination of mineral elements for iron (Fe), manganese ( $\mathrm{Mn})$, magnesium, $(\mathrm{mg})$, zinc $(\mathrm{Zn})$, calcium $(\mathrm{Ca})$, sodium $(\mathrm{Na})$ and potassium $(\mathrm{K})$ and using atomic absorption spectrophotometer (Pye, Unican SP9,Cambridge, UK) (AOAC, 2005)

\section{Anti-nutrient analysis fermented and unfermented samples}

The anti-nutrients tested in this study were hydrogen cyanide, phytate, tannins and oxalate. Hydrogen cyanide and phytate contents were determined following the description of Mbaeyi and Onweluzo (2010), while tannins and oxalates were analyzed spectrophotmetrically at 440500nm as described earlier (Leyva et al., 1990; Doss et al., 2011).

\section{Statistical analysis}

Calculation of means and standard deviations and test of significance (at $p<0.05$ ) were performed using Microsoft Excel office 2007 version and SPSS 16.0 version for Windows program (SPSS, Inc.)

Ogu, G. I., \& Orjiakor, P. I. (2017). Microbiological and nutritional qualities of fermented melon seed shells. International Journal of Life Sciences, 1(2), 1-9. https://doi.org/10.21744/ijls.v1i2.27 


\section{Results and Analysis}

In this study, the microbiological and proximate quality of fermented melon seed shell samples were investigated with a view to generating wealth from the so called 'melon waste'. It was found from the microbiological counts that fermentation significantly $(\mathrm{P}<0.05)$ reduced the microbial load of melon seed shells as shown in Fig. 1. The total fungal counts were significantly high than the total bacterial counts both in the unfermented and fermented samples, indicating that fungal isolates were probably well adapted to the intrinsic and extrinsic factors of melon peels. Also, the fungi possess the requisite enzymatic machinery needed to derive nutrients from the lingo-cellulose material. Additionally, the predominance of fungal species in the fermented products could be attributed to the relatively reduced $\mathrm{pH}$ nature of the medium, which are well known to selectively favour various fungal growth and metabolic activities. The $\mathrm{pH}$ was observed to decrease significantly from 6.7 to 4.2 after fermentation period (Fig. 2). The reduction in pH of the medium is expected because of the acidic by products of fermentation process. The $\mathrm{pH}$ reduction might have in no small measure negatively affected the multiplication and metabolic activities the bacterial population. Previous studies have reported that the acidic $\mathrm{pH}$ ranges were more tolerated by fungi than bacteria (Brock and Madigan, 2003).

The microbial species belonging to genera of Bacillus, Micrococcus, Aerobacter, Rhizopus, Mucor, Aspergillus Penicillium and Candida were isolated from the unfermented sample, while Bacillus, Rhizopus, Aspergillus, Penicillium and Candida spp dominated the fermented sample (Fig 2). Among the predominant isolates, Aspergillus, Penicillium and Bacillus species stood out. According to Adebayo et al., (2014), Aspergillus and Penicillium spp are among the most prevalent fungi responsible for spontaneous fermentation of food products, because they are abundant in the environment (Frisvad and Samson, 2007). Bacillus sp have also been reported to possess efficient fermentative capacities in various legumes and condiments (Achi, 2005). Therefore, these microorganisms that were predominant during the fermentation could be responsible for the fermentation of the substrate.

Our results further revealed that there were significant differences in the proximate contents of the fermented sample when compared with the unfermented control (Table 1). The proximate analysis of the fermented sample revealed a significant $(\mathrm{P}<0.05)$ increase in its moisture contents, crude protein and ash with a decrease in the crude fat and carbohydrate contents after the five day fermetatation perioids. The moisture content of the samples was however lower than those obtained in previous studies from agro-waste peels such as corn-cob (6.00\%), plantain peels (11.43\%) and banana peels (13.49\%) (Abubakar, et al., 2016). Since moisture content of any processed food product plays a key in determining its durability, the values obtained from this study samples suggest that both the fermented and unfermented products may not be easily susceptible to microbial spoilage, hence would serve as a good source of feed supplement.

The result of this study further revealed a significant increase in crude protein content of the fermented sample over the unfermented. The observed increase in crude protein content of the fermented samples could be adduced to the diverse multiple extracellular protein enzymes elaborated by the microorganisms to break down the carbohydrate content of the substrate. This finding is line with the submission of Olufunke et al. (2013), who also reported that some fungi have the potentials to bio-transform starch or sugar to proteins, which could probably lead to rise in content of the proteins during fermentation. This finding is vital because it suggests that fermented melon peel samples could be a potential source of protein fortifier considering the importance of proteins in animal growth and developments. 


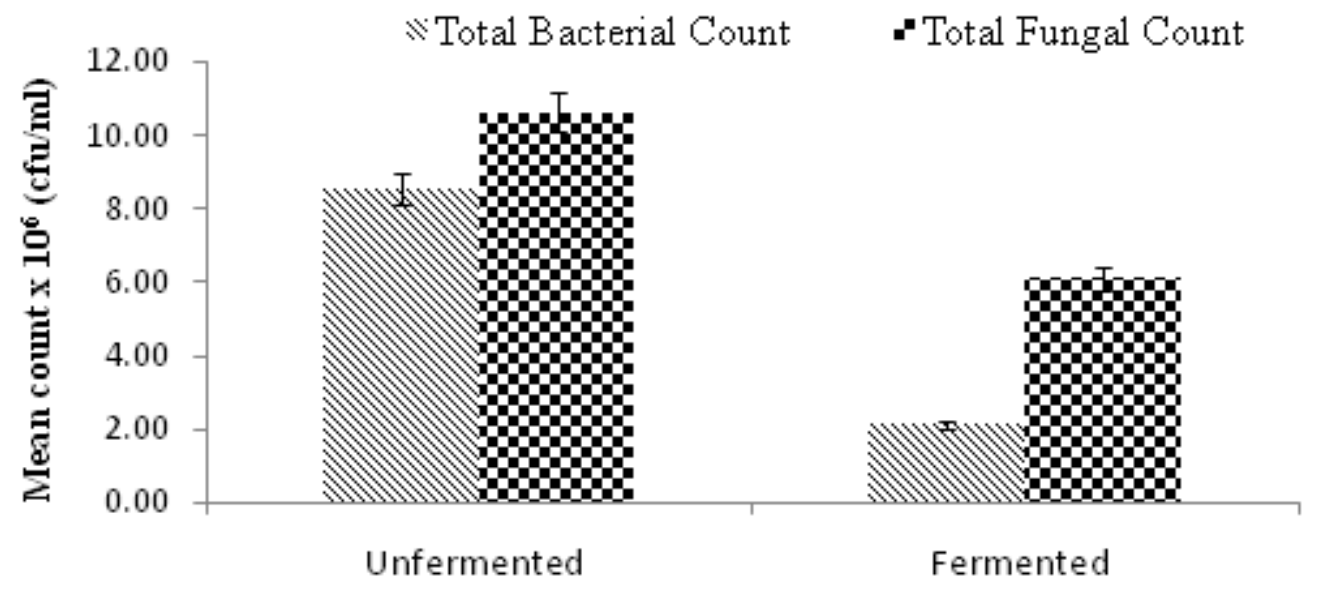

Melon shell Sample

Fig 1: Microbiological counts of unfermented and fermented melon shell samples

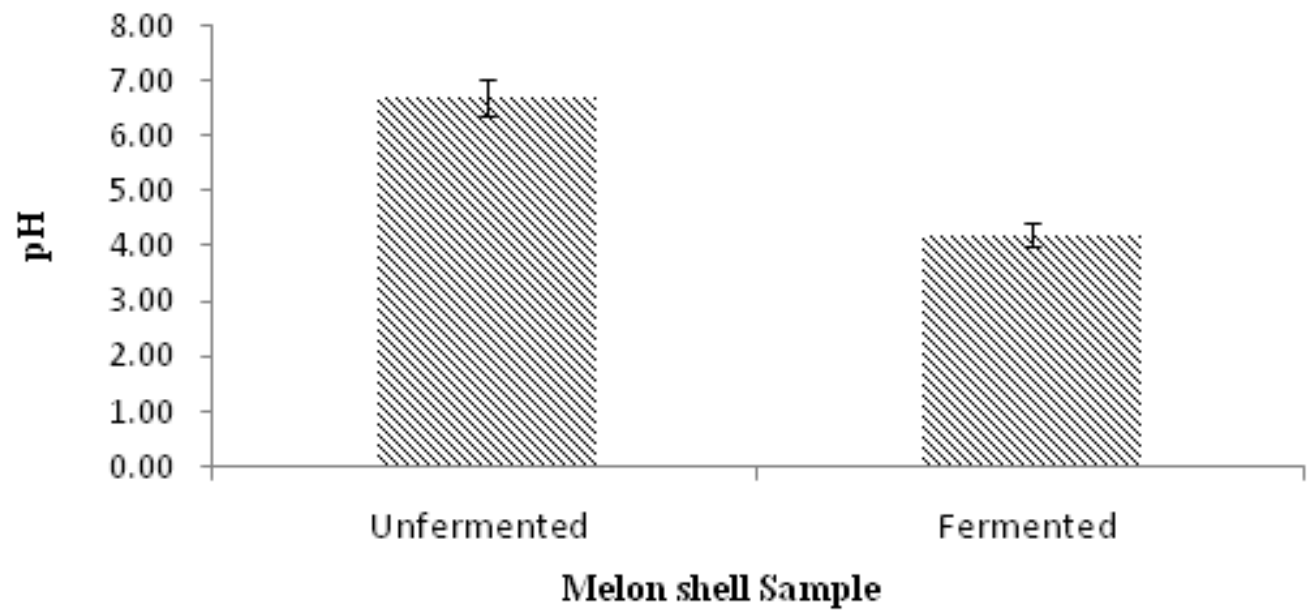

Fig 2: $\mathrm{pH}$ of unfermented and fermented melon shell samples shells. International Journal of Life Sciences, 1(2), 1-9. https://doi.org/10.21744/ijls.v1i2.27 


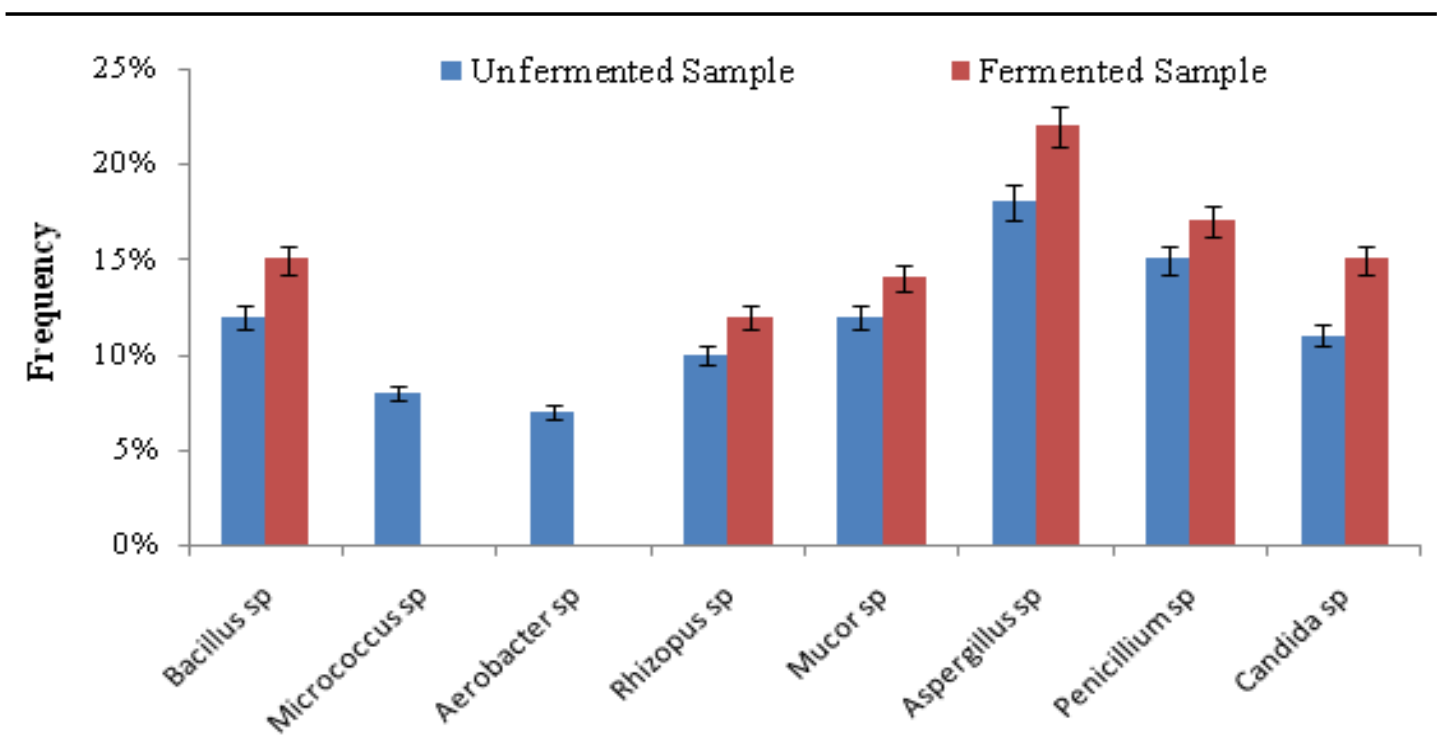

Microbial Isolates

Fig. 3 Microbial Isolates and occurence in unfermented and fermented samples

Table 1: Proximate content of fermented and unfermented melon seed shells

\begin{tabular}{llll}
\hline Parameters & Unfermented Sample & Fermented sample & p-value \\
\hline Moisture (\%) & $3.99 \pm 0.42^{\mathrm{a}}$ & $6.29 \pm 2.62^{\mathrm{b}}$ & 0.000 \\
Crude protein (\%) & $10.89 \pm 0.05^{\mathrm{a}}$ & $16.19 \pm 0.39^{\mathrm{b}}$ & 0.005 \\
Crude fibre (\%) & $23.56 \pm 0.92^{\mathrm{a}}$ & $23.10 \pm 1.42^{\mathrm{a}}$ & 0.021 \\
Crude fat (\%) & $15.91 \pm 0.56^{\mathrm{a}}$ & $14.91 \pm 0.45^{\mathrm{a}}$ & 0.331 \\
Total ash (\%) & $6.35 \pm 1.01^{\mathrm{a}}$ & $12.09 \pm 3.12^{\mathrm{b}}$ & 0.001 \\
Total Carbohydrate (\%) & $39.30 \pm 0.12^{\mathrm{a}}$ & $26.89 \pm 1.99^{\mathrm{b}}$ & 0.011 \\
\hline
\end{tabular}

Mean values with different alphabets are significantly different at $\mathrm{p}<0.05$

Table 2: Mineral constituent of fermented and unfermented melon seed shells

\begin{tabular}{lll}
\hline Parameters & Unfermented sample & Fermented sample p-value \\
\hline $\begin{array}{c}\text { Iron }(\mathrm{mg} / 100 \mathrm{~g}) \\
0.005\end{array}$ & $49.06 \pm 2.03 \mathrm{a}$ & $42.46 \pm 0.03 \mathrm{~b}$ \\
$\begin{array}{c}\text { Potassium }(\mathrm{mg} / 100 \mathrm{~g}) \\
0.001\end{array}$ & $3.09 \pm 0.41 \mathrm{a}$ & $7.01 \pm 0.10 \mathrm{~b}$ \\
$\begin{array}{c}\text { Sodium }(\mathrm{mg} / 100 \mathrm{~g}) \\
0.008\end{array}$ & $59.01 \pm 1.70 \mathrm{a}$ & $50.21 \pm 0.20 \mathrm{~b}$ \\
$\begin{array}{c}\text { Manganese }(\mathrm{mg} / 100 \mathrm{~g}) \\
0.495\end{array}$ & $1.58 \pm 2.40 \mathrm{a}$ & $2.57 \pm 0.42 \mathrm{a}$ \\
$\begin{array}{c}\text { Phosphorus }(\mathrm{mg} / 100 \mathrm{~g}) \\
0.000\end{array}$ & $35.01 \pm 0.87 \mathrm{a}$ & $27.59 \pm 1.53 \mathrm{~b}$ \\
$\begin{array}{c}\text { Calcium }(\mathrm{mg} / 100 \mathrm{~g}) \\
0.000\end{array}$ & $4.11 \pm 0.03 \mathrm{a}$ & $7.90 \pm 4.01 \mathrm{~b}$ \\
$\begin{array}{c}\text { Zinc }(\mathrm{mg} / 100 \mathrm{~g}) \\
0.612\end{array}$ & $35.86 \pm 2.43 \mathrm{a}$ & $36.12 \pm 0.45 \mathrm{a}$ \\
$\begin{array}{c}\text { Magnesium }(\mathrm{mg} / 100 \mathrm{~g}) \\
0.058\end{array}$ & $47.34 \pm 0.23 \mathrm{a}$ & $45.51 \pm 0.22 \mathrm{a}$ \\
\hline
\end{tabular}

Mean values with different alphabets are significantly different at $p<0.05$ 
Table 3: Anti-nutrient analysis of fermented and unfermented melon shells

\begin{tabular}{lll}
\hline Parameters & Unfermented sample & Fermented shell p-value \\
\hline $\begin{array}{c}\text { H. cyanide }(\mathrm{mg} / 100 \mathrm{~g}) \\
0.004\end{array}$ & $2.02 \pm 0.43 \mathrm{a}$ & $1.05 \pm 0.19 \mathrm{~b}$ \\
$\begin{array}{r}\text { Oxalate }(\mathrm{mg} / 100 \mathrm{~g}) \\
0.132\end{array}$ & $30.98 \pm 0.16 \mathrm{a}$ & $16.01 \pm 2.07 \mathrm{a}$ \\
$\begin{array}{c}\text { Tannins }(\mathrm{mg} / 100 \mathrm{~g}) \\
0.312\end{array}$ & $9.56 \pm 0.28 \mathrm{a}$ & $7.34 \pm 0.41 \mathrm{a}$ \\
$\begin{array}{c}\text { Phytate }(\mathrm{mg} / 100 \mathrm{~g}) \\
0.001\end{array}$ & $254.54 \pm 0.15 \mathrm{a}$ & $231.56 \pm 1.23 \mathrm{~b}$ \\
\hline
\end{tabular}

Mean values with different alphabets are significantly different at $\mathrm{p}<0.05$

The increase in ash content of the fermented sample observed in this study suggests an increase in mineral contents. This finding is also important because of the value of minerals in animal diets. Hence, this further supports the eelier findings that fermented melon seed peels will a potential supplement for animal diets. The decrease in the crude fat and carbohydrate contents of the fermented samples suggest degradation and utilization during the fermentation process. Carbohydrates and fats are well known sources of carbon for microbial growth and development. Thus, their reduction could be attributed to their breakdown by the amylolytic and lipolytic enzymes secreted by the microorganisms.

Our results further revealed that fermentation significantly $(\mathrm{P}<0.05)$ lowered the levels of iron, phosphorus, sodium and magnesium of the samples, but increased its potassium, zinc, manganese and calcium mineral contents (Table 2). The presence of potassium, zinc, manganese and calcium mineral in the fermented sample is of great nutritional importance since the macronutrients are essential for animal growth and development. Generally, they help in formation of strong bones and teeth, regulation nerves and mucle formations, proper blood coagulation, active enzymatic cellular metabolism, and maintenance of cell osmotic balance (Soetan et al., 2010). The, other micronutrients, manganese and zinc play important enzymatic and metabolic roles for optimal cellular functions (Soetan et al., 2010). The fermented sample, is thus, nutritionally rich with respect to the presence of some vital mineral nutrients of dietary importance for animals. To enhance the relatively low level of the other macronutrients such as iron that got reduced during fermentation, a measure amount of the unfermented samples could be added to the fermented products to supplement the lost or utilized nutrients.

Additionally, there was a marked reduction in anti-nutritive contents (hydrogen cyanide, oxalate, and phytate) due to fermentation (Table 3 ). This was statistically significant at $P=0.05$. This finding is also vital because the presence of large amount of anti-nutrients has been reported to affect the availability and utilization of some essential minerals by animals (Soetan et al., 2010). Thus, their reduction in this study is of great nutritional importance. Therefore, fermented melon seed shell will be an important nutritional diet or supplement for animals.

\section{Conclusion}

Provide a statement that what is expected, as stated in the "Introduction" chapter can ultimately result in "Results and Discussion" chapter, so there is compatibility. Moreover, it can also be added the prospect of the development of research results and application prospects of further studies into the next (based on result and discussion).

\section{Acknowledgement}

Special appreciation to the Management of Light House Research Laboratory, Warri for assistance in chemical analysis

Ogu, G. I., \& Orjiakor, P. I. (2017). Microbiological and nutritional qualities of fermented melon seed shells. International Journal of Life Sciences, 1(2), 1-9. https://doi.org/10.21744/ijls.v1i2.27 


\section{References}

Abubakar, U. S., Yusuf, K. M., Safiyanu, I., Abdullahi, S., Saidu, S. R., Abdu, G. T., Indee, A. M., "Proximate and mineral composition of corn cob, banana and plantain peels". International Journal of Food Science and Nutrition. Vol. 1, pp. 25-27, 2016.

Achi, O. K., "Traditionally fermented protein condiments in Nigeria”. African Journal of Biotechnology, Vol. 4, pp. 1612-1621, 2005

Adam, I. K., Osoku, A. A, and Bello, A. B., "Nutritional composition of Colocynthis citrullus and Sesanum indicum grown in Obi local government area of Nasarawa state, Nigeria". Elixir Food Science, Vol. 40, pp. $5415-5417,2011$

Adebayo, C. O., Aderiye, B. I., and Akpor, O. B., "Assessment of bacterial and fungal spoilage of some Nigerian fermented and unfermented foods". African Journal of Food Science. Vol. 8, pp. 140-147, 2014

Alexopoulos, C. J., and Mims, C. W., "Introductory Mycology". 3rd Edition. John Wiley and Sons, New York. 1979, pp. 269.

AOAC., "Official Methods of Analysis, Association of Analytical Chemists". 15th edition, Washington D. C. USA. 1990, pp. 1121-1180.

AOAC., "Official Methods of Analysis". 19th Edition. Association of Official Analytical Chemists, Washington, DC. USA. 2005, pp. 777-784.

Arcentales, G. A. T., Lucas, M. A. P., Guerrero, J. A. C., \& Gordín, R. G. (2017). Evaluation for the Reduction of NH3 Contamination Risks. International Journal of Life Sciences (IJLS), 1(2), 10-17.

Arnawa, I. K., Sukerta, I. M., Martiningsih, N. G. A. E., \& Astuti, P. S. (2017). Minapolitan Area Development Strategy: An Effort to Increase Fisherman Income, Gianyar Regency, Bali Indonesia. International Journal of Life Sciences (IJLS), 1(2), 39-47.

Barnett, H. C., and Hunter, B. B., "Illustrated Genera of Imperfect Fungi", 3rd edition. Minneapolis Burgress Publishing Company Minneapolis. 1972, pp. 241.

Brock, T. D., and Madigan, M. T., "The Biology of Microorganisms". 8th Edition Prentice Hall International, London. 2003, pp. 840.

Doss, A., Pugalenthi, M., Vadivel, V. G., Subhashini, G., and Subash, R. A. "Effects of processing technique on the nutritional composition and anti-nutrients content of under-utilized food legume Canavalia ensiformis L. DC”. International Food Research Journal, Vol. 18, pp 965- 970, 2011.

Frisvad, J. C., and Samson, R. A., "Identification of Aspergillus and Penicillium”. In: Food Mycology; Emerging mold problems and spoilage in food and beverages (Samson R.A., Dijksterhuis J., Houbraken J., Rico E., Johnson S., Editors). Proceedings of Food Mycology, 2007, pp. 124-127.

Holt, J. G., Krieg, N. R., Sneath, P. H. A., Staley, J. T., Williams, S. T., "Bergey's Manual of Determinative Bacteriology", 9th edition. Lippincot: Williams and Wilkins. Philadelphia, USA. 2002, pp 131, 151 156, 542.

Jain, P., Jain, A., Singhai, R., \& Jain, S. (2017). Effect of Biodegradation and Non Degradable Substances in Environment. International Journal of Life Sciences (IJLS), 1(1), 58-64.

Jurado, W. C. C., Pérez, A. V. P., Quiroz, A. M. V., \& Gámez, M. R. (2017). Environmental Impact On Electrical Networks Near The Manabita Litoral. International Journal of Life Sciences (IJLS), 1(2), 18-27.

Ledward, D. A., Taylor, A. J., and Lawrive, R. A., "Upgrading waste for food and feeds". 3rd Edition. Butterorth, U.S.A. 2003, pp. 321.

Leyva, J. A. M., Artiga, M. P. H., Méndez, M. M. A., and Pér, J. J. Q., “Atomic absorption and UV-VIS absorption spectrophotometric determination of oxalate in urine by ligand exchange extraction". Clinica Chimica Acta, Vol. 195, pp. 47-56, 1990.

Mbaeyi, I. E. and Onweluzo, J. C., "Effect of sprouting and pre-gelatinization on the physicochemical properties of sorghum-pigeon pea composite blend used for production of breakfast cereal". Journal of Tropical Agriculture, Food, Environment and Extension, Vol. 9, pp. 8-17, 2010.

Ogbonna, P. E., "Floral habits and seed production characteristics in Egusi melon (Colocynthis citrullus L.)" Journal of Plant Breeding and Crop Science, Vol. 5, pp. 137-140, 2013.

Ogu, G. I., \& Orjiakor, P. I. (2017). Microbiological and Nutritional Qualities of Fermented Melon Seed Shells. International Journal of Life Sciences (IJLS), 1(2), 1-9.

Ogu, G. I., Ezeadila, J., and Ehiobu, J. M., "Antioxidant and antimicrobial activities of Dialium guineense (Willd) leaf extract". Pharmacy and Pharmacology Research, Vol. 1, pp. 1-7, 2013.

Ogunsiji, A. S., \& Ladanu, W. K. (2017). A Theoretical Study of Performance Measures in the Strategic and Corporate Entrepreneurship of Firms. International Journal of Life Sciences (IJLS), 1(1), 49-57.

Olufunke, O. E., and Ogugua, C. A., "Solid State Fermentation of Cassava Peel with Trichoderma viride (ATCC 36316) for Protein Enrichment". International Journal of Biological, Biomolecular, Agricultural, Food and Biotechnological Engineering, Vol. 7, pp. 202-209, 2013. 
Omer, A. M. (2017). Identifying, Developing, and Moving Sustainable Communities through Application of Bioenergy for Energy or Materials: Future Perspective through Energy Efficiency. International Journal of Life Sciences (IJLS), 1(1), 9-39.

Saxena, A. (2017). The Impact of Nutrition on the Overall Quality of Life Adolescent Girls are Living Across the City of Kota. International Journal of Life Sciences (IJLS), 1(1), 40-48.

Singh, D. (2017). Leaf Phenology of Cassia Sieberiana L. in KSUSTA Campus of Kebbi State, Nigeria. International Journal of Life Sciences (IJLS), 1(1), 1-8.

Soetan, K. O., Olaiya, C. O., and Oyewole, O. E. "The importance of mineral elements for humans, domestic animals and plants" A review. African Journal of Food Science, Vol. 4, pp. 200-222, 2010.

Sulistiawati, N. P. A., Kartini, L., \& Yuliartini, M. S. (2017). Identification of Development Phases and Changes Shoots Flowering Orange Siam Plants. International Journal of Life Sciences (IJLS), 1(2), 28-38.

Sutapa, I. K., Sutapa, I. N., \& Susila, I. N. D. (2017). Implementation of Active Rest in Participatory Ergonomics Decrease Workload and Women Musculoskeletal Complaints of Parking in Mall Ramayana Denpasar. International Journal of Life Sciences (IJLS), 1(2), 48-54.

\section{Biography of Authors}

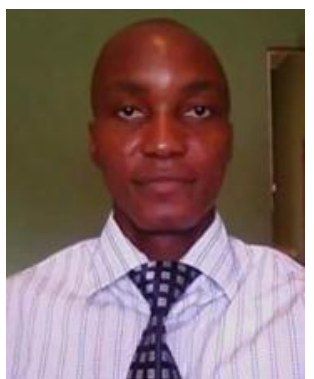

Gideon I Ogu is currently a lecturer at Biological Sciences Department of Novena University, Ogume, Delta State, Nigeria. He is a PhD student at the University of Benin, Benin City, Nigeria. His study area is Environmental and Public Health Microbiology. His area of research interest is crude oil bioremediation, medicinal plants and biochemistry, and waste recycling. He has published over 20 papers in medicinal plants, crude oil remediation, and nutrition and health challenges. His current research works include resolving the biomass biodegradation paradox vis-à-vis axenic-consortia bacteria degradation capacities, bioremediation potentials of exotic bacteria from common invertebrates, bioelectricity production, biofuel generation from agro-waste and quantitative public health risk assessment of retailed foods.

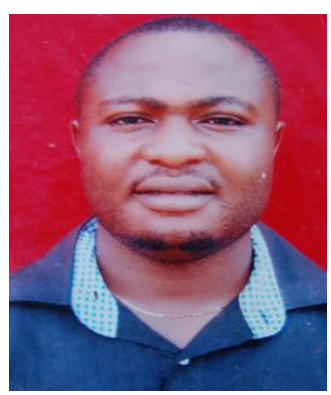

Paul I Orjiakor is a lecturer at Ekiti State University, Ado-Ekiti, Ekiti State, Nigeria. He is currently a PhD student in Microbiology Department at University of Benin, Benin City, Nigeria. His area is Environmental and Public Health Microbiology. He is an experience teacher and researcher. His research interests include waste management, and phytoremediation of crude and refined oil pollutants.

Ogu, G. I., \& Orjiakor, P. I. (2017). Microbiological and nutritional qualities of fermented melon seed shells. International Journal of Life Sciences, 1(2), 1-9. https://doi.org/10.21744/ijls.v1i2.27 